\title{
Вплив COVID-19 на перебіг вагітності, пологів, післяпологового періоду та стан новонароджених
}

\author{
О.М. Кетова \\ Заклад вищої освіти «Полтавський державний медичний університет», Полтава, Україна
}

Анотація. Оцінено перебіг вагітності, пологів, післяпологового періоду, а також стан новонароджених та перебіг періоду новонародженості дітей, народжених від жінок із COVID-19. Проведено ретроспективний аналіз історій вагітності жінок із COVID-19 та історій новонароджених. 3'ясовано, що COVID-19 має схильність до тяжкого перебігу у вагітних із екстрагенітальною патологією та $є$ ризиком розвитку передчасних пологів та збільшення показань до оперативного розродження. Майже 50\% вагітностей завершуються передчасними пологами, а стан >70\% новонароджених ускладнюється синдромом дихальних розладів.

Ключові слова: COVID-19, вагітність, період новонародженості.

\section{Вступ}

За даними літератури, специфічних клінічних проявів COVID-19 у вагітних не зареєстровано, але дослідження свідчать про несприятливі результати вагітності у пацієнток із COVID-19 [1, 2]. Також викликає значний інтерес питання можливої вертикальної передачі інфекції від матері до дитини [3].

Мета: оцінити перебіг вагітності, пологів, післяпологового періоду, а також стан новонароджених та перебіг періоду новонародженості у дітей, народжених від жінок із COVID-19.

\section{0б'єкт і методи дослідження}

Проведено ретроспективний аналіз історій вагітності жінок із COVID-19, що проходили лікування у КП «Міський клінічний пологовий будинок» ПМР у 2021 р., та історій новонароджених.

\section{Результати та їх обговорення}

Проаналізовано дані 92 жінок з підтвердженим COVID-19: 84 вагітні, 4 - 3 аномальною матковою кровотечею, 4 - 3 післяпологовими ускладненнями. Гінекологічні хворі мали безсимптомний перебіг COVID-19. Вагітність ранніх термінів (8-14 тиж) мали 4 жінки, в них відмічено легкий перебіг захворювання. У 1 вагітної відбувся самовільний викидень, інші виписані з негативними тестами і прогресуючими вагітностями. 80 вагітних терміном 22-40 тиж проходили стаціонарне лікування (середній вік - 30,8 $\pm 4,2$ року). Тяжкий перебіг COVID-19 діагностовано у 26 (32,5\%) вагітних, з них кисеньзалежними виявилися 23 (88,5\%), 3 (11,5\%) потребували штучної вентиляції легень. У 75\% вагітних відмічали лихоманку $\left(37,2-38,7^{\circ} \mathrm{C}\right)$ та зниження сатурації до 95-87\%. Рівні аспартатамінотрансферази, аланінамінотрансферази та С-реактивного білка були підвищені у 73,8\% пацієнток.

Всі вагітні з тяжким перебігом COVID-19 мали те чи інше хронічне соматичне захворювання: $57,7 \%$ - гіпертонічну хворобу, 11,5\%-цукровий діабет, 38,5\% - варикозне розширення вен нижніх кінцівок, у $50,0 \%$ індекс маси тіла становив $>30$ кг/ $\mathrm{M}^{2}$. 33 вагітні були розроджені, 21 (63,6\%) шляхом кесаревого розтину, у 12 (36,4\%) відбулися пологи, при чому у 2 - з антенатальною загибеллю плода. У 16 (48,5\%)

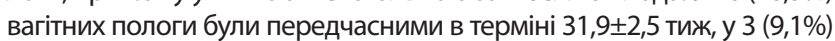
пологи відбулися двійнею. У 6 (18,2\%) породіль післяпологовий період ускладнився субінволюцією матки, 3 (14,3\%) після кесаревого розтину проведена релапаротомія з екстирпацією матки.

3 35-ти новонароджених 16 (45,7\%) народилися передчасно в терміні гестації 31,9 $\pm 2,5$ тиж, 19 (54,3\%) були доношеними та зрілими. Кількість балів за шкалою Апгар на 1-й хвилині становила

Кетова Олена Миколаївна — кандидат медичних наук, заклад вищої освіти «Полтавський державний медичний університет», Полтава, Україна. E-mail: zyatina_t@ukr.net

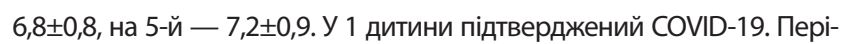
од новонародженості у $27(77,1 \%)$ випадках ускладнився синдромом дихальних розладів, 4 (11,4\%) дитини народилися у стані асфіксії, у 2 (5,7\%) діагностована вроджена пневмонія, у $9(25,7 \%)$ - жовтяниця, у $6(17,1 \%)$ - церебральне збудження, у $3(8,6 \%)$ - кон'юнктивіт, у $3(8,6 \%)$ - піодермія, у $6(17,1 \%)$ - анемія, у 4 (11,4\%) — кандидоз. Також діагностовано внутрішньошлунковий крововилив, порушення м'язового тонусу, ентероколіт і шуми серця. 1 дитина померла на 6-ту добу після пологів.

\section{Висновок}

COVID-19 має схильність до тяжкого перебігу у вагітних з екстрагенітальною патологією, $\epsilon$ ризиком передчасних пологів і збільшення показань до оперативного розродження. При COVID-19 майже 50\% вагітностей завершуються передчасними пологами, а стан $>70 \%$ новонароджених ускладнюється синдромом дихальних розладів.

\section{Список використаної літератури}

1. Рябоконь О.В., Черкаський В.В., Рябоконь Ю.Ю. (2021) Короновірусна хвороба у вагітних: сучасний стан питання. Інфекційні хвороби, 1(103): 45-49.

2. Ellington S., Strid P., Tong V.T. et al. (2020) Characteristics of women of reproductive age with laboratoryconfirmed SARS-CoV-2 infection by pregnancy status — United States, January 22-June 7, 2020. MMWR Morb. Mortal. Wkly Rep., 69(25): 769-775.

3. VallejoV., Ilagan J.G. (2020) A postpartum death due to Coronavirus disease 2019 (COVID-19) in the United States. Obstet. Gynecol., 136(1):52-55. D0l: 10.1097/AOG.0000000000003950.

\section{Influence of COVID-19 on pregnancy, childbirth, postpartum and newborn}

\section{E.M. Ketova}

Poltava State Medical University, Poltava, Ukraine

Abstract. The course of pregnancy, childbirth, postpartum, as well as the condition of newborns and the neonatal period in children of women with COVID-19 were evaluated. A retrospective analysis of pregnancy histories of women with COVID-19 and newborns were conducted. COVID-19 is prone to severe in pregnat with extragenital pathology and a risk of premature birth and increased indications for preterm birth. Almost $50 \%$ of pregnancies are at risk of premature birth, and $>70 \%$ of newborns are complicated by respiratory disorders.

Key words: COVID-19, pregnancy, neonatal period.

Ketova Elena M. - Candidate of Medical Sciences, Poltava State Medical University, Poltava, Ukraine. E-mail: zyatina_t@ukr.net 